\title{
A Conceptualist Turn: The Ontological Status of Created Species in Late Greek Patristic Theology
}

\author{
Dirk Krausmüller \\ Affiliate Member, Institut für Byzantinistik und Neogräzistik, Universität \\ Wien, Wien, Austria \\ dkrausmuller@hotmail.com
}

\begin{abstract}
The realist ontology of Maximus the Confessor cannot be considered representative of the Greek theological discourse of his time. Several authors writing in the sixth, seventh and eighth centuries denied the existence of immanent universals in creation. This position was first formulated as a response to the nominalist Trinitarian theology of John Philoponus. As time went on, however, it began to serve a different function. It was now used to emphasise the distinction between God and creation.
\end{abstract}

\section{Keywords}

Maximus Confessor - John Philoponus - conceptualism - realism - created species

Maximus the Confessor, the most productive theological author of the Late Patristic period, was a realist. He believed that created species had objective existence, not by themselves, but in their instantiations, which they bound together since they themselves were indivisible. This position was by no means new. It had first been formulated in the fourth century when Gregory of Nyssa created a parallel between the Trinity and the human species in order to prove the oneness of God. This does not, however, mean that it went unchallenged. In the middle of the sixth century the philosopher and theologian John Philoponus denied the existence of common natures not only in creation but also in the divinity. Philoponus was condemned as a heretic. Thus one might think that his speculation had no impact and that the Greek theological discourse remained wedded to the realist cause. Yet this is not the case. Monophysite and Chalcedonian theologians formulated a nuanced response to Philoponus' 
position: they rejected his Tritheism but accepted that his conceptualist ontology was valid for created being. In the late sixth, seventh and eighth centuries this position was then restated in several texts, which suggests that it had become the mainstream view. This means that we need to reconsider Maximus' role. He can no longer be regarded as the representative of a uniform Greek tradition. Indeed, it may well be that he was an outsider.

The seventh-century theologian Maximus the Confessor has long been considered the most fruitful thinker of the Late Patristic period. He defended almost single-handedly the belief that each of the two natures in the incarnated Word had a will and an operation of its own. ${ }^{1}$ Equally impressive is his spiritual oeuvre. In a series of treatises Maximus succeeded in creating a coherent framework, which encompassed theology, anthropology and cosmology. ${ }^{2}$ One topic that interested him greatly was the ontological status of genera and species. His most detailed discussion of the topic is found in the treatise Ambigua ad Iohannem, which John Scottus Eriugena later translated into Latin. ${ }^{3}$

All things that are peculiarly distinguished from each other through their own differences are united commonly through the universal identities and are pushed to oneness and sameness with each other through a generic principle of nature. For example, the genera have oneness and sameness and indivisibility because they are united with each other according to substance. For none of those that are universal and comprehending and generic are at all divided together with those that are particular and comprehended and peculiar. For if something does not gather that which is divided naturally it can no longer be generic, but loses its own singular oneness by being divided together with them. ... And the species likewise receive sameness with each other because they are liberated from the variety in difference. And the individuals have oneness and sameness with each other because they receive the agreement with each other in the species. ${ }^{4}$

1 See P. Allen, B. Neil, Maximus the Confessor and his Companions, Oxford, 2002.

2 See e.g. T. Th. Tollefsen, The Christocentric Cosmology of Maximus the Confessor, Oxford, 2007.

3 See C. Kavanagh, "The Impact of Maximus the Confessor on John Scottus Eriugena," in: The Oxford Handbook of Maximus the Confessor, ed. P. Allen, B. Neil, Oxford, 2015, pp. 480-499.

4 Maximus the Confessor, Ambigua ad Iohannem, Patrologia graeca 91, Paris, 1865, col. 1312:

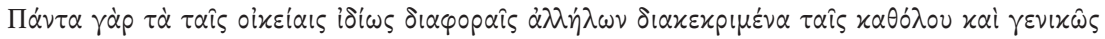


For Maximus genera and species were not simply concepts that the human mind abstracted from individuals. He regarded them as real entities. Yet at the same time he insisted that these entities cannot exist outside the individuals.

If the universals subsist in the particulars and do not at all admit of the principle of being and subsisting by oneself it is clear to everybody that when the particulars perish the universals will not remain either. ${ }^{5}$

As is well known, Maximus was not the first Greek theologian to assert the existence of immanent universals. Already in the fourth century Gregory of Nyssa had argued that the human nature only existed in its instantiations but that it was nevertheless not divided into them. For this reason, he had insisted that one should use the word 'human being' only in the singular because members of the human species only differed from each other through accidents, which were ontologically posterior. ${ }^{6}$ Gregory, however, had only spoken about the lowest species. He was looking for an analogy that would help him to explain why Father, Son and Spirit are one God. References to genera such as 'animal' would have weakened his argument because they would have suggested the existence of a higher genus in God. A much closer parallel to Maximus' speculation is found in a text from the second quarter of the sixth century, Leontius of Byzantium's Christological treatise Contra Nestorianos et Eutychianos. ${ }^{7}$ There we read:

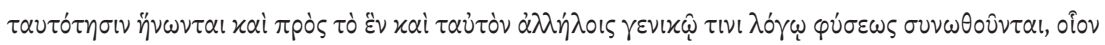

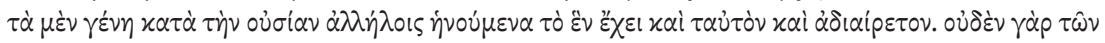

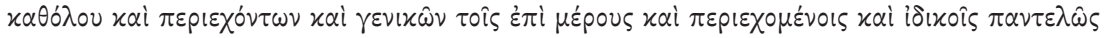

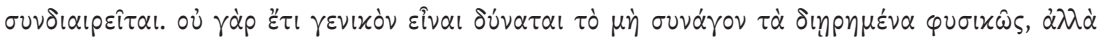

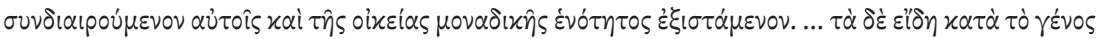

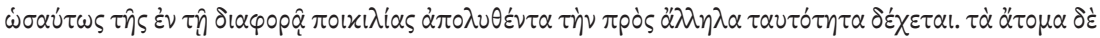

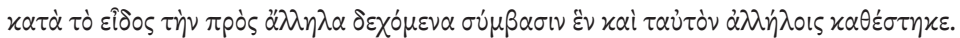

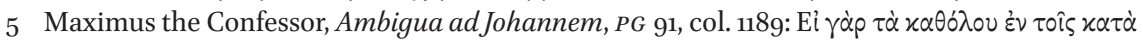

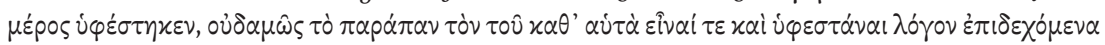

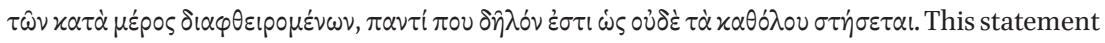
is adapted from Nemesius of Emesa, De Natura Hominis, 43, ed. M. Morani, Leipzig, 1987, p. 129. See A. Louth, Maximus the Confessor, Oxford, 1996, p. 96.

6 Gregory's ontology has often been discussed. See e.g. Ch. Erismann, L'homme commun. La genèse du réalisme ontologique durant le haut Moyen Age, Paris, 2011, 149-185, and J. Zachhuber, "Universals in the Greek Church Fathers," in: Universals in Ancient Philosophy, ed. R. Chiaradonna, G. Galluzzo, Pisa, 2013, pp. 425-470, esp. pp. 436-447.

7 On Leontius of Byzantium see B. E. Daley, "A Richer Union: Leontius of Byzantium and the Relationship of Human and Divine in Christ," Studia Patristica, 24 (1993), pp. 239-256. On Maximus' indebtedness to him see S. E. Gersh, "Per Se Ipsum': The Problem of Immediate and Mediate Causation in Eriugena and His Neoplatonic Predecessors," in: Jean Scot Erigène et l'histoire de la philosophie, ed. R. Roques (Paris, 1977), pp. 367-376. 
All beings are joined to each other through the universal commonalities and are then divided from each other by the specific differences, and these neither confuse what is distinct by these unions, nor separate what is united by the distinctions, but if one is to speak paradoxically, and follow the Fathers, they are united in division and distinguished in union. ${ }^{8}$

In this passage Leontius not only speaks about the hierarchy of genera and species but also declares that universals have the power to unify created beings. As we have seen Maximus expressed himself in virtually the same way. This striking resemblance is no coincidence. A native of Constantinople, Leontius had moved to Palestine where he joined a circle of learned monks who had a keen interest in cosmological speculation. ${ }^{9}$ They were the heirs of a tradition that stretched back to the late fourth century. Originally the focus had been on the writings of Origen of Alexandria and Evagrius Ponticus who had been influenced by Middle Platonism. ${ }^{10}$ At some point, however, the study of Porphyry's Isagoge must have been added to the curriculum. This engagement resulted in a modification of Origen's conceptual framework. It was now thought that creation was held together not only by transcendent ideas but also by immanent universals. There can be no doubt that Maximus belonged to the same milieu. According to an early biography that has only survived in Syriac he entered a Palestinian monastery where the writings of Origen were being studied. ${ }^{11}$ Indeed, it has long been known that he borrowed key concepts from the Alexandrian theologian. ${ }^{12}$

It is possible that the realist interpretation of the arbor Porphyriana suggested itself to the Origenists because Gregory of Nyssa had already introduced

8 Leontius of Byzantium, Contra Nestorianos et Eutychianos, ed. and tr. B. E. Daley, Leontius

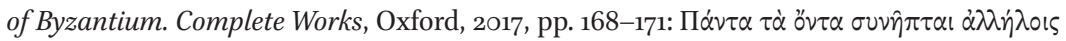

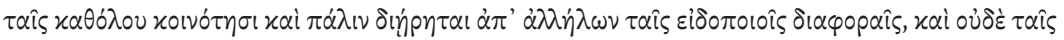

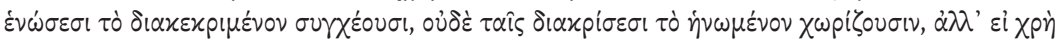

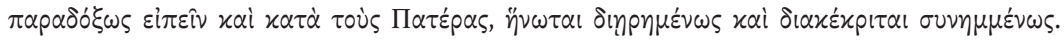
Daley's translation is slightly modified.

9 See D. Hombergen, The Second Origenist Controversy. A New Perspective on Cyril of Scythopolis' Monastic Biographies as Historical Sources for Sixth-Century Origenism, Rome, 2001, pp. 133-138; and D. Krausmüller, "Origenism in the Sixth Century: Leontius of Byzantium on the Pre-Existence of the Soul," Journal of Late Antique Religion and Culture, 8 (2014), pp. $46-67$.

See E. A. Clark, The Origenist Controversy. The Cultural Construction of an Early Christian Debate, Princeton, 1992.

11 S. Brock, "An Early Syriac Life of Maximus the Confessor," Analecta Bollandiana, 91 (1973), pp. 299-346, esp. p. 315.

12 See e.g. H. U. von Balthasar, Kosmische Liturgie. Das Weltbild Maximus' des Bekenners, Einsiedeln, 1961, pp. 102-105. 
the immanent universal into the theological discourse. If this was the case one could speak of a continuous realist tradition within Greek Patristic theology, which John Eriugena then transplanted into the West. ${ }^{13}$ Yet this does not necessarily mean that in the East realism ruled supreme. Indeed, a radically different picture emerges when we turn from cosmological speculation, which had always been the preserve of the Origenists, to the Christological debate, which was conducted by authors from widely differing backgrounds. These authors were, of course, also aware of Gregory of Nyssa's conceptual framework. Yet they found it increasingly difficult to reconcile it with their Christological models. Trinitarian theology had not been Gregory's only concern. Insistence on the oneness of nature also helped him to explain how the benefits of the incarnation were passed on to all human beings. ${ }^{14}$ Yet this so-called 'physical doctrine of salvation' had a serious drawback. It gave the impression that the Word had assumed the sum total of human individuals, including not only Jesus but also Judas and Caiaphas. In the early sixth century the Monophysite theologian Severus of Antioch sought to overcome this problem by arguing that the divine Word assumed an individual human nature. This was a momentous step although it seems that Severus was not aware of its implications. Indeed, he considered himself to be a faithful adherent of Gregory of Nyssa's teachings. Significantly, his statements about soteriology are entirely traditional. ${ }^{15}$

Severus' innovation was harshly criticised by Chalcedonian theologians. His contemporary John of Caesarea insisted that the divine Word assumed the entire humanity. ${ }^{16}$ Yet this does not mean that he had found a way to exclude the undesirable consequences of such a view. His counterarguments are entirely specious. Confusing the extensional and intensional meanings of 'nature', he claims that Severus wished to cut asunder the 'account of being', that is, the sum total of all qualities characterising a member of a species. ${ }^{17}$ It was left to an author of the next generation, Leontius of Byzantium, to formulate a coherent position. In his treatise Contra Nestorianos et Eutychianos, which I have already mentioned, he seems to accept Gregory of Nyssa's position. ${ }^{18}$ Yet when

\footnotetext{
13 See Zachhuber, "Universals in the Fathers," p. 448.

14 See Zachhuber, "Universals in the Fathers," p. $45^{2}$.

15 See Zachhuber, "Universals in the Fathers," pp. 46o-461.

16 See A. Grillmeier, Jesus der Christus im Glauben der Kirche. 2/2: Die Kirche von Konstantinopel im 6. Jahrhundert, Freiburg-Basel-Wien, 1989, pp. 56-57.

17 John of Caesarea, Apologia concilii Chalcedonensis, ed. M. Richard, Iohannis Caesariensis presbyteri et grammatici opera quae supersunt (Corpus Christianorum. Series Graeca, 1), Turnhout, 1977, pp. 49-59, esp. p. 5o.

18 See, however, D. Krausmüller, "Making Sense of the Formula of Chalcedon: the Cappadocians and Aristotle in Leontius of Byzantium's Contra Nestorianos et Eutychianos," Vigiliae Christianae, 65 (2011), pp. 484-513, esp. pp. 506-507.
} 
he later wrote his Solutiones he had changed his mind. This is evident from a brief dialogue between a Monophysite and a Chalcedonian, which Leontius inserts into his text. The Monophysite asks which human nature it was that the divine Word assumed, that in an individual or that in the entire species. The Chalcedonian replies that this distinction is nonsensical since the content of the human nature is always the same, regardless of whether it is found in a single individual or in the whole species. Then he adds the comment that nature does indeed appear in many but is not for this reason many natures. This comment has been discussed by Johannes Zachhuber who concludes from it that Leontius still follows Gregory of Nyssa's lead. ${ }^{19}$ This interpretation, however, is only valid if the 'many' are to be identified as hypostases. This is not necessarily the case as can be seen from the last part of the dialogue, which Zachhuber does not consider. It consists of another question of the Monophysite, and the Chalcedonian's final reply.
A. Did he (sc. the Word) assume an individual nature, then?
O. Certainly, but one which is the same as the species. ${ }^{20}$

This exchange shows clearly that Leontius accepts the Monophysite claim that the assumed humanity is an individual nature. There can be little doubt that he took this step because he wished to rule out a scenario where the Word becomes incarnate in the entire human race. In any case, he could in this instance not have replaced individual nature with hypostasis because this would have resulted in a Nestorian position. At the same time, however, he insists that the content of this individual nature is the same as in all other members of the species. For him this clearly constitutes an ontological link between the different individuals since he denies that one can speak of many natures. This is still realism of a sort but no longer the extreme form that Gregory of Nyssa had advocated. This shift had an important consequence for Trinitarian theology: it was no longer possible to uphold the strict analogy that Gregory of Nyssa had drawn between humanity and divinity. This meant that Chalcedonian theologians had to find new paradigms. Leontius of Jerusalem, for example, compares the Trinity not with three members of the human species but with the soul and its three faculties. ${ }^{21}$

19 Zachhuber, "Universals in the Fathers," pp. 457-458.

20 Leontius of Byzantium, Solutiones, ed. and tr. Daley, Leontius of Byzantium, pp. 217-218:

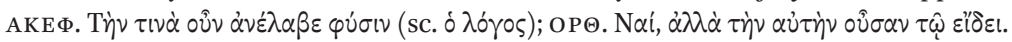

21 See D. Krausmüller, "Under the Spell of John Philoponus: How Chalcedonian Theologians of the Late Patristic Period Attempted to Safeguard the Oneness of God," Journal of Theological Studies, 68 (2017), pp. 625-649. 
Leontius of Jerusalem was especially sensitive to this issue because in the third quarter of the sixth century the debate had taken a new turn. The conceptual problems of Gregory of Nyssa's model were not limited to the humanity of Christ. It could equally be claimed that the whole Trinity was dragged into the incarnation, because the three divine persons shared one undivided nature. Here, too, the obvious solution was to speak of three individual natures. This step was taken in the middle of the sixth century by the Alexandrian philosopher and theologian John Philoponus. ${ }^{22}$ Philoponus was well aware of the fact that the same properties were found in Father, Son and Spirit alike. This seemed to suggest that in the Trinity there existed not only three individual natures but also one common nature. Such a position, however, would be manifestly heretical because it would introduce a fourth component into the Trinity. How Philoponus dealt with these problems can be seen from a passage in his treatise Contra Themistium:

But look, enough has already been said and demonstrated by us about this. They are compelled to say either that God is one according to number (and thus Judaize) or that there are four hypostases, or at the extreme, to fall into the atheism held by the Epicureans. We have demonstrated that the nature, which is said to be general does not even have its own existence in any of those things that exist. Rather, it is either nothing at all - which is the truth - or it is established in our thought alone from each of these (sc. particulars). ${ }^{23}$

This statement is evidently inspired by Aristotle's De anima I.1 (402b7-8) where it is famously claimed that 'animal, as the universal, is regarded either as nonexistent or, if existent, as logically posterior' ( $\tau \dot{0} \delta \dot{\varepsilon} \zeta \hat{\varphi}$ $\varepsilon \sigma \tau \iota \nu \ddot{\eta} ~ u ̈ \sigma \tau \varepsilon \rho \circ \vee$ ). As Marwan Rashed has pointed out this is a strictly nominalist reading of Aristotle. ${ }^{24}$ Philoponus will not even accept that the universal is a concept in the human mind, most likely because he wished to exclude the notion of innate ideas, which could be regarded as reflections of some objective reality. 25

22 On Philoponus' theological oeuvre in general see H. Chadwick, "Philoponus the Christian Theologian," in: Philoponus and the Rejection of Aristotelian Science, ed. R. Sorabji, London, 1987 , pp. $41-56$.

A. Radde-Gallwitz, The Cambridge Edition of Early Christian Writings, I: God, Cambridge, 2017, p. 365. Cf. A. Van Roey, "Les fragments trithéites de Jean Philopon," Orientalia Lovaniensia Periodica, 11 (1980), pp. 135-163, esp. 148.

24 M. Rashed, L'héritage aristotélicien. Textes inédits de l'Antiquité, Paris, 2007, pp. 352-357.

25 See A. C. Lloyd, The Anatomy of Neoplatonism, Oxford, 199o, p. 71. 
With this conceptual framework Philoponus challenged the central tenet of traditional Trinitarian theology, the existence of immanent universals. This, however, was not his only innovation. In his treatise De Trinitate he attacked another facet of the mainstream position, the conceptualisation of the Trinity as a species consisting of three individuals.

For when the property of each hypostasis is added to that which is 'God', to each all in all, it makes them each different in species from the rest. It is the same with 'animal', which is generally said of all animals, though they vary by species. When 'rational' or 'irrational' is added to 'animal', then they are differentiated in species form one another: one animal is rational, another animal irrational. Therefore, when 'Father' and 'Son' and 'Holy Spirit' are added to 'divinity', it makes God the Father not the same as God the Son and the divine Spirit. ${ }^{26}$

Here Philoponus claims that the Trinity should be conceptualised as a genus consisting of three species, each of which is only instantiated once. This means that the three characteristics 'ingeneracy', 'generacy' and 'procession', which identify Father, Son and Holy Spirit, take on a different meaning. Whereas Basil of Caesarea and Gregory of Nyssa had compared them with the (inseparable) accidents that constitute individual human beings Philoponus gives them the function of specific differences. ${ }^{27}$ This raises the question: why would he have taken such an unusual step? One could argue that it gave greater coherence to the Monophysite position. By treating the hypostatic idioms as parts of natures, Philoponus could identify hypostasis with nature. Yet this may not have been his only reason. It is also possible that he wished to overcome perceived flaws in the Cappadocian conception of the Trinity. He may have considered problematic the comparison of hypostatic idioms with mere accidents and therefore preferred specific differences, which are of a higher ontological order. Moreover, he may have been unhappy with the strict separation between the natural and hypostatic dimensions, which suggested that there was composition in God and that the hypostatic idioms were not God in the true sense. ${ }^{28}$ With the modifications that he introduced 'ingeneracy', 'generacy' and 'proces-

26 Radde-Gallwitz, Cambridge Edition, I: God, 362. Cf. Van Roey, "Les fragments trithéites", p. 159 .

27 For Gregory of Nyssa cf. J. Zachhuber, Human Nature in Gregory of Nyssa. Philosophical Background and Theological Significance (Supplements to Vigiliae Christianae, 46), Leiden, 2000, p. 120.

28 See A. Radde-Gallwitz, Basil of Caesarea: A guide to his life and doctrines, Eugene, 2012, pp. 224-235. 
sion' became part of the divine nature rather than being somehow extrinsic to it. The integration of all elements constituting the Father, the Son and the Holy Spirit is not threatened by the existence of a common divine genus since this genus has no objective reality. Thus one can argue that Philoponus' model has two different but related consequences: horizontally it emphasises the differences between the three divine persons while vertically it achieves a higher degree of unity.

Philoponus' innovative Trinitarian theology provoked a storm of protest. Within a short period of time he was branded a heretic not only by the leaders of the Monophysite church to which he belonged but also by the Chalcedonian ecclesiastical establishment. His enemies focused entirely on his refusal to regard the divine nature as an immanent universal, which they regarded as a threat to Christianity's status as a monotheist religion. There was very little awareness of the problematic features of the Cappadocian model. Only one author, Eulogius, the Chalcedonian patriarch of Alexandria, declared that in the case of God one should not speak of accidents and their addition to nature. He did, however, not adopt Philoponus' solution. ${ }^{29}$

This does not mean that Philoponus did not have an impact on the discussion about universals. His model did not only apply to the Trinity. He also denied the real existence of created species such as the human race. In this he followed Gregory of Nyssa who had also created an analogy between divinity and humanity. Some of Philoponus' adversaries reacted by restating Gregory's point of view. ${ }^{30}$ Yet not everybody was so uncompromising. In a number of texts one encounters an intermediary position. This position first appears in a Monophysite treatise against Philoponus. ${ }^{31}$ The author of this text quotes passages from Philoponus' Trinitarian writings and in each case adds statements of earlier theologians, which are meant to show that Philoponus deviates from the Patristic consensus. One of these statements is taken from Gregory of Nazianzus' Fifth Theological Oration.

What then, might they say, is there not one divinity also for pagans, as those among them say who engage in more perfect philosophy, and is there not for us one humanity, the whole race? Nevertheless, there are many gods and not one, just as there are human beings. But there that which is common has a oneness that is seen only in the mind, whereas

\footnotetext{
29 Photius, Library, codex 23o, in: Fozio, Biblioteca, ed. L. Canfora, S. Micunco, N. Bianchi, C. Schiano, Pisa, 2016, pp. 486-487.

$30 \quad$ See below note 56 .

$31 \quad$ See the description of this text by Van Roey, "Les fragments trithéites," p. 138.
} 
the individuals are to a very great extent separated from each other through time and affects and power. ${ }^{32}$

In this passage Gregory of Nazianzus seeks to show that only the Christian God is one in the true sense of the word. In order to make his case he points out that there are more differences between human beings than there are between the three divine persons. Similar statements are found in Gregory of Nyssa's treatises. But the conclusions that the two authors draw from this observation differ radically from one another. Whereas Gregory of Nyssa makes a sharp distinction between nature and accidents, which allows him to uphold the oneness of nature even in created being, Gregory of Nazianzus assumes that the number of accidents has an impact on the nature itself. He conceives of each individual as a whole, a bundle of both natural and accidental properties. Thus he can conclude that the divinity where each person possesses only one hypostatic idiom is 'more one' than the human species.

From the choice of this proof text it is evident that the author of the Monophysite treatise did not object to Philoponus' conceptual framework in principle. In fact, Gregory of Nazianzus's views bear a striking resemblance to those of Philoponus: as we have seen Philoponus, too, regarded each divine person as a whole consisting of common and proper idioms. All that he challenged was its applicability to the divinity. Indeed, it is possible that Philoponus held the same view about created being. When one of his followers, Elias, returned to the Monophysite mainstream he composed a confession of faith, which includes the following passage:

I rely on Cyril, teacher of highly exact doctrines, who is by no means minded to allow talk of several natures even in respect of us creatures divided both by will, by different places and a myriad of different things yet nevertheless attaining consubstantiality. ${ }^{33}$

This passage is also interesting because it shows that the Monophysite ecclesiastical establishment insisted on the reality of universals in the created order.

32 Gregory of Nazianzus, Oratio 31, 15.1-7, ed. and tr. P. Gallay, M. Jourjon, Grégoire de Nazianze, Discours 27-37 (Discours Théologiques) (Sources Chrétiennes, 250), Paris, 1978,

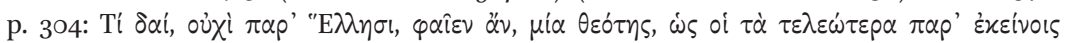

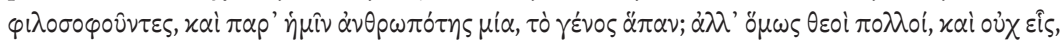

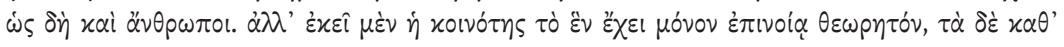

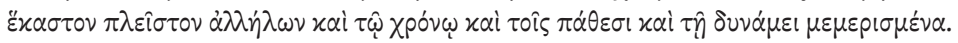

33 R. Y. Ebied, A. van Roey and L. R. Wickham, Peter of Callinicum, Anti-Tritheist Dossier (Orientalia Lovaniensia Analecta, 10), Leuven, 1981, p. 6o. 
It is evident that they would not have approved of the stance of the author of the Monophysite treatise against Philoponus. Nevertheless, one can argue that this stance was a logical consequence of the Monophysite position. As we have seen, in their polemics with the Chalcedonians the Monophysites insisted that the flesh was an individual nature because otherwise the divine Word would become incarnate in the entire human race. It is likely that the position reflected in Elias' confession of faith was a simple case of theological conservatism, without any consideration of the conceptual problems arising from it.

Complete rejection of a particularist ontology was more commonly found in the writings of Chalcedonian theologians who insisted on the reality of universals even in their Christological statements. A typical example is Anastasius, the Chalcedonian patriarch of Antioch. Anastasius repeatedly denies the existence of individual natures and insists that the divine Word assumed the universal human nature. ${ }^{34}$ It needs, however, to be said that Anastasius is incapable of constructing an argument that would rule out the assumption by the divine Word of all human beings. Thus it should not surprise us too much that the argument presented in the Monophysite treatise is also found in Chalcedonian writings. It appears first in a text that directly targets Philoponus, a Chalcedonian gloss added to his Christological treatise Arbiter. ${ }^{35}$ The reader is told not to accept Philoponus' claim that the oneness of God exists only in the human mind and is then informed:

For this is the case with created beings, where the common and the one is seen in thought only, not as in the case of God, as Gregory (of Nazianzus) says. ${ }^{36}$

It could be argued that Philoponus' Chalcedonian opponents accepted his conceptual framework for created being not because they considered it to be correct but because it allowed them to focus exclusively on Trinitarian theology where so much more was at stake. Yet such an interpretation is unsatisfactory because we also encounter the quotation from Gregory of Nazianzus in Chalcedonian texts that are not polemical in nature. What this meant for

\footnotetext{
34 See Zachhuber, "Universals in the Fathers," p. $45^{8}$.

35 For a discussion and translation of this text see U. M. Lang, John Philoponus and the Controversies over Chalcedon in the Sixth Century. A Study and Translation of the Arbiter (Spicilegium Sacrum Lovaniense, 47), Leuven, 2001.

36 F. Diekamp, Doctrina Patrum de Incarnatione Verbi. Ein griechisches Florilegium aus der

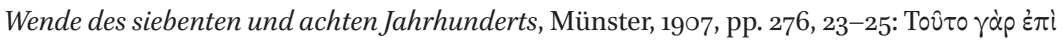

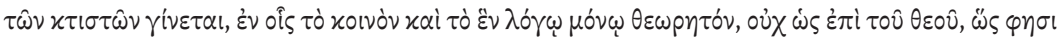
Грpróplos.
} 
Gregory of Nyssa's conceptual framework can be seen most clearly in the Praeparatio, a theological handbook, which Theodore of Raithou composed in the late sixth century. ${ }^{37}$ Theodore is, of course, aware of the fact that in the Cappadocian model substance is common and not individual. He explains that the human species is called a common substance 'because it is as a whole present in each person without separation and imparts to them its name and its reality'. ${ }^{38}$ In order to emphasise this point he then declares that one should never use the term 'human being' in the plural. ${ }^{39}$ This entire argument is a summary of Gregory of Nyssa's treatise Ad Graecos ex communibus notionibus. ${ }^{40}$ At this point one might therefore conclude that Theodore accepts Gregory's position that universals have a reality of their own and that they establish an ontological bond between individuals.

Yet immediately afterwards the argument takes a new and completely unexpected direction. Theodore remarks that Scripture also refers to human beings in the plural. Unlike Gregory of Nyssa he does not simply dismiss such statements as incorrect usage. Instead he explains that the plural is justified through the existence of real differences within the human species. In order to illustrate his point, he first mentions the distinction between male and female and then produces a quotation from Gregory of Nazianzus.

We are not only composite but also opposed to each other and even to ourselves, and nor do we quite remain the same on a single day, but we always flow and change both in body and in soul. And I do not know if this does not also apply to the angels and to all nature that is most sublime and comes after God, even though they are simple and steadier in the good through the closeness to the highest good. ${ }^{41}$

Theodore of Raithou, Praeparatio, ed. F. Diekamp, Analecta Patristica. Texte und Abhandlungen zur griechischen Patristik, Rome, 1938, esp. p. 210, 2-21. On Theodore cf. A. Grillmeier and Th. Hainthaler, Jesus der Christus im Glauben der Kirche, 2/3: Die Kirchen von Jerusalem und Antiochien, Freiburg-Basel-Wien, 2002, pp. 117-119.

38 Theodore of Raithou, Praeparatio, ed. Diekamp, p. 209, 26-p. 210, $2 \dot{\omega} \varsigma$ ö $\lambda \eta \dot{\alpha} \tau \mu \dot{\eta} \tau \omega \varsigma$ हेv

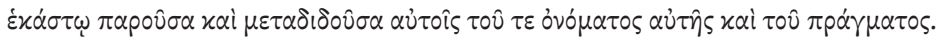

39 Theodore of Raithou, Praeparatio, ed. Diekamp, p. 210, 2-11.

40 Gregory of Nyssa, Ad Graecos ex communibus notionibus, ed. F. Mueller, Gregorii Nysseni opera, 3.1, Leiden, 1958, pp. 19-33.

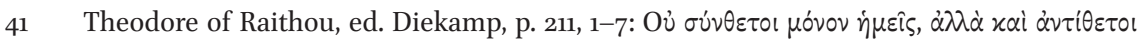

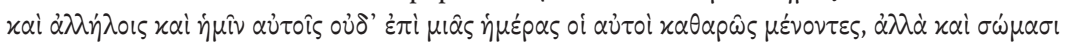

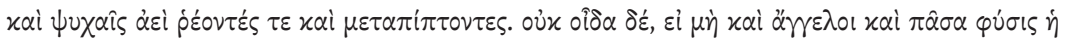

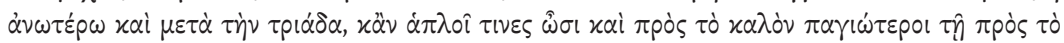

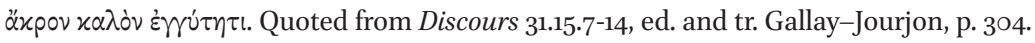


This passage is also taken from Gregory of Nazianzus' Fifth Theological Oration. There it immediately follows the statement that we found quoted in the Monophysite treatise and paraphrased in the Chalcedonian gloss on the Arbiter. That Theodore also had this earlier statement in mind can be seen from the conclusion of his argument where he explains again why the Bible speaks of human beings and even angels in the plural.

In all nature and substance after the holy Trinity oneness is seen only through conceptualisation whereas the many and that which separates one from the other and each one from himself exists in reality and actuality. Therefore the appellation in the singular is preserved reverently and very carefully for the super-substantial and truly singular divinity by holy Scripture. ${ }^{42}$

In this passage Theodore makes a radical distinction between the Trinity and species in the created order. In the latter case the secondary substance is nothing more than a mental construct, without any force to unite individuals, which alone are real.

A very similar statement is then found in a text from the seventh century, the Christological florilegium Doctrina Patrum, which was most likely compiled by Anastasius Apocrisiarius, the representative of the Pope in Constantinople. ${ }^{43}$

That in the case of all that have come to be oneness is only seen in abstraction and what one calls common and universal does not subsist, and that oneness in reality and truth is preserved in the strict sense only for the divine and transcendent substance. ${ }^{44}$

Comparison shows that this statement is based on the passage found in Theodore of Raithou's Praeparatio. It is rephrased in such a way that the linguistic dimension has disappeared. Now we are told even more clearly that common

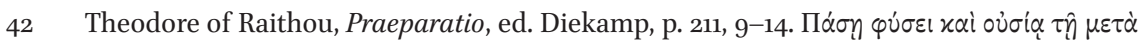

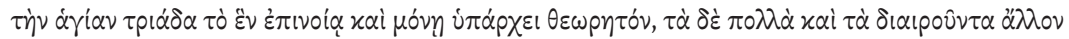

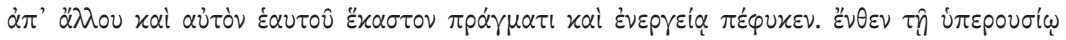

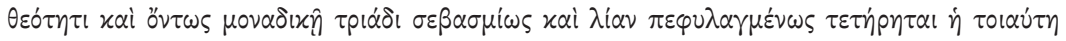

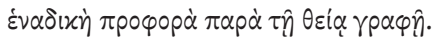

43 J. Stiglmayr, "Der Verfasser der Doctrina Patrum de Incarnatione," Byzantinische Zeitschrift, 18 (1919), pp. 14-40.

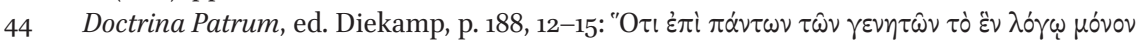

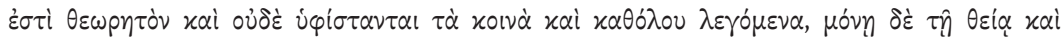

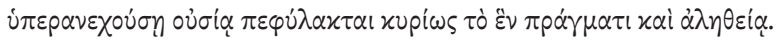


natures do not exist. From the context it is clear that this must refer to universals in re and not to universals ante rem as would be required by the Cappadocian model. In the following paragraph we are then informed why only the nature of God can be one.

For in the case of the uncircumscribed divinity one cannot speak of spatial distance as one can in our case, nor of a difference in will or power or opinion, which produce in us the real distinction between one and another. $^{45}$

Such a statement is not found in Theodore's handbook. It does, however, have a counterpart in the confession of faith of Elias where differences in place and will are mentioned. This is further evidence of exchanges between Monophysites and Chalcedonians. There are no direct references to Gregory of Nazianzus but there is similar emphasis on the transience of created being. We read that species cannot be real because their instantiations are not always the same but change over time through birth and death.

The Doctrina Patrum consists of older theological texts and of additions made by the compiler. The passage under discussion most likely belongs to the latter category since no author is identified. If the compiler is indeed Anastasius Apocrisiarius this would be of particular interest because he was a close companion and collaborator of the arch-realist Maximus the Confessor. ${ }^{46}$

The next link in the chain is a passage in the Expositio fidei of John of Damascus, which dates to the early eighth century. ${ }^{47}$ John declares that one must distinguish 'being seen in reality' and 'being seen in thought' and then adds the following statement:

In the case of all creatures, then, the division of the hypostases is seen in reality whereas the commonality and the connection and the oneness are seen in reason and thought. For we think that Peter and Paul are of the same nature and have one common nature. For each of them is

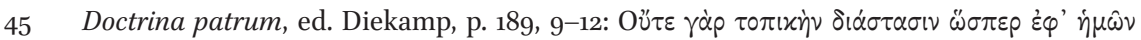

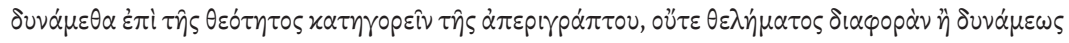

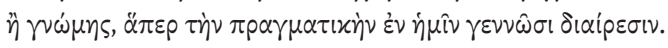

46 On Anastasius see P. Allen and B. Neil, Maximus the Confessor and his Companions, pp. 88-101.

47 On John of Damascus see A. Louth, StJohn Damascene: Tradition and Originality in Byzantine Theology, New York, 2002. 
rational mortal animal and each flesh endowed with a rational and intellectual soul. This common nature, then, is seen in reason. ${ }^{48}$

John then explains that the common nature cannot be real because the hypostases differ in place and time, intention and power, form and shape, habitus and mixture, and rank and occupation, before concluding: 'For this reason one

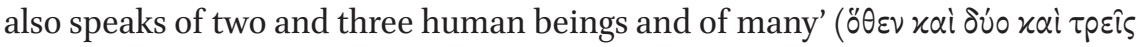

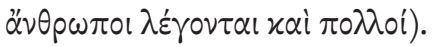

This passage has already been analysed in some detail by Christophe Erismann and Richard Cross. Erismann rightly points out that John's position is not reconcilable with Gregory of Nyssa's hyper-realism. Yet he is still of the opinion that John was a realist for he states: 'Claiming that the unity of hypostases of the same species is perceived by reason does not imply, according to John of Damascus, that substantial unity is only conceptual and dependent on the observer'.49 Accordingly, he finds rather puzzling John's claim that the name 'human being' can be used in the plural.

Richard Cross comes to a different conclusion. He declares: 'This passage is part of a near quotation from Pseudo-Cyril, and in the original form part of the strongest evidence in favour of this writer's nominalism. ${ }^{50}$ What Cross considers to be John's source, the Pseudo-Cyrillian treatise De Trinitate, has been shown to be a late compilation based on the Expositio fidei. ${ }^{51}$ Thus one would have to conclude that John, too, was a 'nominalist'. This is, however, not Cross' position. He points out that John's oeuvre contains passages where the existence of immanent universals is accepted and therefore concludes that a realist reading must be attempted. ${ }^{2}$

48 John of Damascus, Expositio fidei, 8, ed. B. Kotter Die Schriften des Johannes von Damaskos, 2 (Patristische Texte und Studien, 12), Berlin, 1973, p. 28, 224-231: 'E $\pi \dot{i} \mu \dot{\varepsilon} \nu$ oûv $\pi \dot{\alpha} \nu \tau \omega \nu \tau \hat{\omega} \nu$

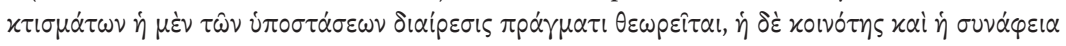

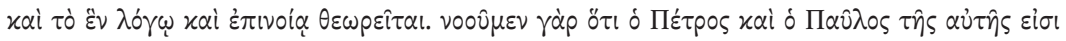

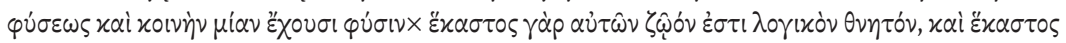

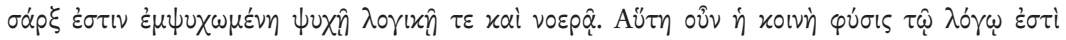
$\theta \varepsilon \omega p \eta \tau \eta \dot{.}$.

49 Ch. Erismann, "Catachrestic Plural Forms. Gregory of Nyssa and Theodore Abu Qurrah on Naming and Counting Essences," British Journal for the History of Philosophy, 22 (2014), pp. 39-59, esp. p. 5 .

R. Cross, "Perichoresis, Deification, and Christological Predication in John of Damascus," Mediaeval Studies, 62 (2000), pp. 69-124, esp. p. 85.

$5^{1} \quad$ V. Conticello, "Pseudo-Cyril's 'De Ss. Trinitate': A Compilation of Joseph the Philosopher," Orientalia Christiana Periodica, 61 (1995), pp. 117-129.

$5^{2} \quad$ See Cross, "Perichoresis, Deification," p. 85. 
Such an approach is highly problematic. It assumes that John had a coherent view on this topic, which is by no means certain. I would argue that it is more fruitful to focus on the different discourses in which John participated. Neither Erismann nor Cross is aware of the fact that John's argument has a long pedigree. Indeed, it is most likely a reworking of the passage in the Doctrina Patrum, which we have discussed before. The structure of the argument is the same - in both cases nature in the created order is juxtaposed with nature in the divinity - and the lists of distinguishing features are largely identical. Thus we can conclude that John's argument, too, does not accord the common nature an objective existence outside the human mind. Indeed, one can argue that this point is even further emphasised through the description of the process of abstraction. Thus John's distinction between common nature and individual hypostasis is misleading. In reality there are only individual natures, as John makes clear when he speaks of 'many human beings'.

We can conclude that in different parts of John's oeuvre mutually exclusive conceptual frameworks are set out. This does not, however, mean that John simply reproduced Gregory of Nyssa's model. That matters are not so straightforward can be seen from the following passage.

Nature is considered either in mere contemplation (for it does not subsist by itself); or commonly in all co-specific hypostases, connecting them, and it is called nature seen in the species; or wholly the same in assumption of accidents in one hypostasis, and it is called nature seen in an individual. ${ }^{53}$

In this passage John of Damascus distinguishes between three different meaning of nature. The first two options are in keeping with the teachings of Basil of Caesarea and Gregory of Nyssa. There are no universals ante rem, which would be separate from their instantiations, but only universals in re, which bind together the instantiations in which they exist. By contrast, the third option is decidedly odd. According to classical Trinitarian theology there should be no need for it since the nature in one individual is the common nature that is found in all individuals. The reason for its addition reveals itself when we

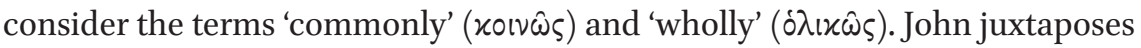
them but it is clear that they do not introduce a distinction: the nature in all

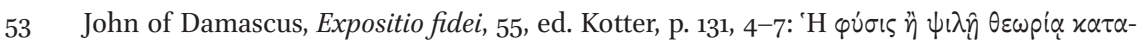

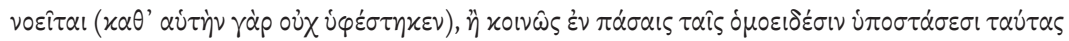

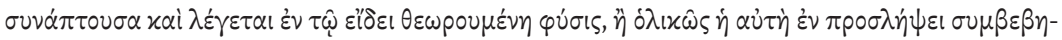

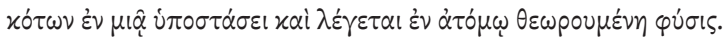


hypostases should also be complete and the nature in one hypostasis common. As Johannes Zachhuber has pointed out, one would instead have expected jux-

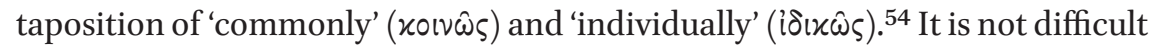
to see why John did not make such a statement. Had he done so he would have introduced the contrast of 'common nature' (

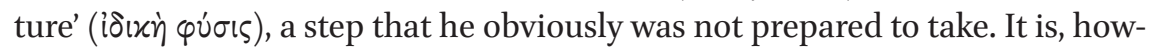
ever, questionable whether the concept of an individual nature has disappeared with John's modification. One could argue that it is already present in the distinction between nature in the species and nature in the individual. John's reference to the hypostatic idioms, which is rather clumsily inserted into the text, provides no solution because it is not the common but the individual nature to which these idioms accede. ${ }^{55}$ This raises the question: how can John then claim that the common nature binds together the hypostases? The following Christological application provides us with an answer. There John claims that the divine Word assumed 'the nature in the individual, which is the same as

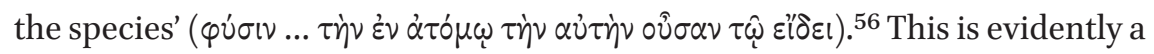
paraphrase of Leontius of Byzantium's statement that the divine Word assumed 'an individual nature ... which is the same as the species' ( $\tau \dot{\eta} \nu \tau i v \dot{\alpha} . .$.

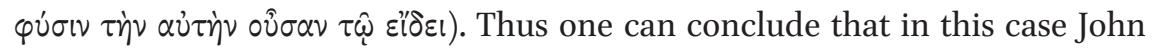
subscribes to a watered-down version of realism. The existence of individual natures is conceded but it is claimed that the lack of differences between them constitutes an ontological link.

The discussion so far has shown that the Greek Patristic discourse was by no means monolithic. As Erismann has already suggested Gregory of Nyssa's hyper-realist understanding of universals was not very popular in the sixth to eighth centuries. ${ }^{57}$ The evidence presented so far supports this view. Quotations from Gregory of Nyssa's treatises are found in several texts. ${ }^{58}$ Yet this does not mean that theologians had found a way to reconcile his conceptual framework with the demands of Christology. Two approaches can be identified. Au-

54 Zachhuber, "Universals in the Fathers," p. 467-468.

55 Zachhuber offers another interpretation of the phrase 'in assumption of accidents'. He thinks that for John the individual nature was qualified by characteristic idioms even before it became a hypostasis and that it differed in this respect from the common nature. See Zachhuber, "Universals in the Fathers," p. 467-468.

56 John of Damascus, Expositio fidei, 55, ed. Kotter, p. 131, 11.

57 Erismann, “Catachrestic Plural Forms," p. 48.

58 Quotations from Gregory of Nyssa's writings are found e.g. in Eutychius of Constantinople, De natura et hypostasi, tr. P. Ananian, "L'opuscolo di Eutichio patriarca di Constantinopoli sulla 'Distinzione della natura e persona'," in: Armeniaca. Mélanges d'Études Arméniennes, publiées à l'occasion du $250^{e}$ anniversaire de l'entrée des Pères Mekhitaristes dans l'Île de Saint-Lazare (1717-1967), Venice, 1969, pp. 355-382, esp. p. 365. 
thors either opted for indifference realism or they denied the objective existence of universals and declared that they only existed in the human mind that abstracts them from individual beings. The former position can be traced back to Leontius of Byzantium whereas the latter position was first formulated by John Philoponus. To judge by the surviving texts, it was more popular than its counterpart. We have seen that over the course of two hundred years it appeared in a number of texts. Comparison shows that there was an unbroken tradition. Each author takes the statement of his immediate predecessor as his starting point and then adds further features. ${ }^{59}$

It needs, however, to be emphasised that in all cases the quotation from Gregory of Nazianzus is the only point of reference. No attempt is made to justify conceptualism through recourse to the philosophical discourse. To my knowledge there is only one exception, the Alexandrian patriarch Eulogius, who flourished in the early seventh century. ${ }^{60}$ Eulogius also rejects the existence of immanent universals in the clearest terms.

For the Father is not divided from his wisdom and sanctifying power, being worshipped in one nature, not being divided into one part and another, as is the case with us, who through the incommunicability of the idioms and the difference of activity are divided into parts and suffer the difference from each other through the complete cut. ${ }^{61}$

Here, too, the difference of idioms and activities is presented as proof for the non-existence of immanent universals in creation. This shows again that there was a stock of arguments, which were employed by various authors. Yet in Eulogius' case this is not the entire story for he continues.

59 John was not the last Byzantine author to hold such a view. In the tenth century Michael, the archimandrite of the Dalmatos monastery, wrote a speech about the founder saints, which includes a section about doctrine that is lifted from the Doctrina patrum. See Peter Hatlie, "The Encomium of Ss. Isakos and Dalmatos by Michael the Monk. Translation and Notes," in: Eukosmia. Studi miscellanei per il. $75^{\circ}$ di Vincenzo Poggi S.J., ed. V. Ruggieri,

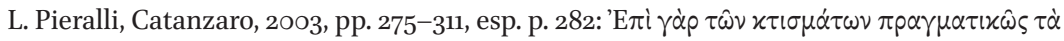

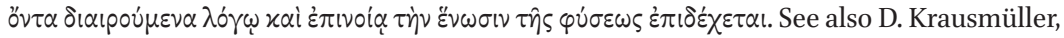
'Beyond the filioque: Michael the Stoudite, Nicetas the Paphlagonian and Metrophanes of Smyrna on the Trinity', forthcoming in Byzantinoslavica.

6o On Eulogius, see A, Grillmeier-Th. Hainthaler, Jesus der Christus im Glauben der Kirche, 2/4: Die Kirche von Alexandrien mit Nubien und Äthiopien, Freiburg, 199o, pp. 66-72.

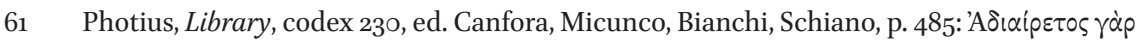

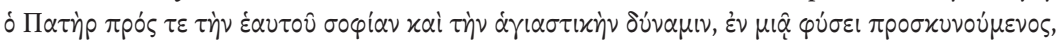

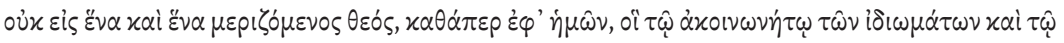

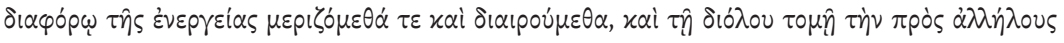
$\delta\llcorner\alpha \varphi \circ \rho \alpha \dot{\nu}$ i $\varphi$ $\sigma \tau \dot{\alpha} \mu \varepsilon \theta \alpha$. 
For in the case of the divine substance we do not conceive of the one as we do in our case, where one cannot even see oneness in the strict sense. For in our case the one in number is not one in the strict sense. For that which in our case is called one is not one in the strict sense but a certain one. And this is both one and not one, since it carries the appellation 'one' and is nevertheless divided into many. ${ }^{62}$

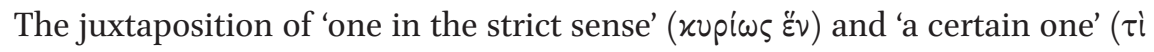
$\varepsilon v)$ and the claim that the latter is one in name only is derived from a philosophical text, most likely Proclus' Elements of Theology ${ }^{63}$ Eulogius clearly had looked around for arguments that would support his two contentions, that nature was one in God and multiple in human beings, and lighted on the writings of the Neoplatonists because they, too, were not willing to accept the existence of immanent universals in the material world. ${ }^{64}$ Thus the case for particularism, which Philoponus had made through a conceptualist reading of Aristotelian philosophy, was reinforced through recourse to the Platonic tradition.

The discussion about the ontological status of genera and species in the sixth to eighth centuries was not conducted in the abstract. What caused Monophysite and Chalcedonian authors to water down or entirely abandon Gregory of Nyssa's hyper-realism were problems inherent in Trinitarian theology and Christology. Yet as time went by the conceptualist model also began to appear in texts that were not devoted to the solution of these problems. Their authors seem to have been motivated by the wish to distinguish more sharply between God and creation than had hitherto been the case. This raises the question: how does the realist Maximus the Confessor fit into this picture? In his Opuscula dogmatica Maximus repeatedly discusses Christological topics. Yet he never addresses the problem that bedevilled other authors: how could it be avoided that the divine Word incarnated in the entire human race? This makes it difficult to establish what his position was. He may have been of the opinion that this was not a necessary consequence of realism, or he may simply have dodged the problem because he found it untractable. As regards the

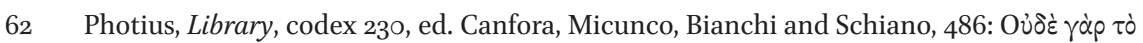

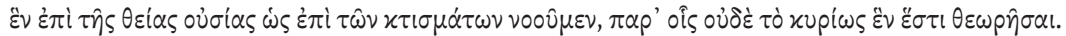

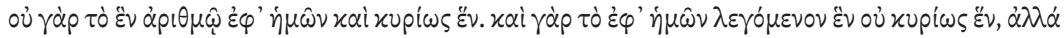

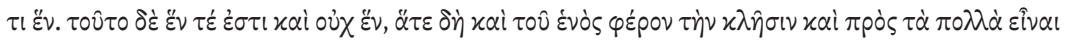

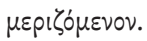

63 See Proclus, Elements of Theology, ed. E. R. Dodds, The Elements of Theology. A Revised Text, with Translation, Introduction and Commentary, $2^{\text {nd }}$ ed. Oxford, 1963, prop. 2, 2, 15-25, prop. 4, 4, 9-18.

64 See e.g. R. Cross, "Gregory of Nyssa on Universals," Vigiliae Christianae, 56 (2002), pp. 372-410, esp. pp. $375^{-376 .}$ 
second concern, the distinction between God and creation, Maximus seems to have been more in line with the mainstream. As Grigory Benevich has pointed out he avoids drawing a parallel between the three divine persons and three individuals in the human species and once even intimates that he considers it inappropriate. ${ }^{65}$ Unfortunately, he gives us no clear idea why this should be so. On balance, it is unlikely that he denied the existence of universals in creation when he spoke about the Trinity. It rather seems to be the case that he put more emphasis on the oneness of God than Gregory of Nyssa had done.

In sum: The realist ontology of Maximus the Confessor cannot be considered representative of the Greek theological discourse. Several authors writing in the sixth, seventh and eighth centuries denied the existence of immanent universals in creation. This position was first formulated as a response to the nominalist Trinitarian theology of John Philoponus. As time went on, however, it began to serve a different function. It was now used to emphasise the distinction between God and creation. Most authors supported their argument with a quotation from Gregory of Nazianzus who had declared that in created being the great number of accidental differences made the existence of immanent universals impossible. However, in at least one case the influence of Neoplatonism can also be discerned.

65 G. Benevich, "Maximus Confessor's polemics against Tritheism and his Trinitarian teaching," Byzantinische Zeitschrift 105 (2012), pp. 595-6o9, esp. p. 6o7. 